\title{
DIFFERENT SKILLS - DIFFERENTIATED LEARNING PLANS: A STRATEGIC COMPROMISE TOWARDS MATH SUCCESS
}

\author{
Filomena Soares ${ }^{1}$, Ana Paula Lopes ${ }^{2}$, Maria Paula Nunes ${ }^{1}$ \\ ${ }^{1}$ Polytechnic Institute of Porto (P.PORTO) / ESEIG (PORTUGAL) \\ ${ }^{2}$ Polytechnic Institute of Porto (P.PORTO) / ISCAP - CICE / UIE (PORTUGAL)
}

\begin{abstract}
Personal development and realisation through academic success is an overall objective of Higher Educational Institutions $(\mathrm{HEI})$, promoting the embracement of an open and fruitful future to their students. These students enrol in several Higher Education courses after attending well distinguished secondary school programs. The impact of these different backgrounds, with its inherent differentiated basic skills, is a general and worldwide challenge, fundamentally when facing some specific "constructive" subjects like foreign languages and Mathematics.
\end{abstract}

In this paper we present a project developed in a Math course, with the first year students from the Accounting and Management Bachelor Degree in the School of Management and Industrial Studies (ESEIG). This project, which started in the academic year 2012/13, proved to be a success, both in terms of acceptance by the students and course global assessment results. We will describe all the methodologic steps connected to its development, implementation and maintenance, ranging from project submission to Scientific and Pedagogical boards for approval, student's background "characterisation", teachers and staff involvement in the different parts of the project, among many others. The project results over the last three years will be presented, assessing its pros and cons and we will also analyse its transferability to other courses and/or subjects, one of our actual major concerns.

Like any other project that tries to promote success in some "historically critical" courses, there are many obstacles, objections and problems both in its implementation and, moreover, in its pursuit. However, it is not possible to develop a conscientious work, when confronted with recurrent student's difficulties, just "move forward" without even trying to change "something".

Keywords: Educational Experiences, Higher Education, Mathematics Curricula, Active Learning, Student Engagement, (Un)Success.

\section{INTRODUCTION}

With a history of more than 25 years the School of Management and Industrial Studies (ESEIG), extinguished last 31th of July, "aimed at the education of technical staff for managerial and technological areas, as well as at the creation of solid links with the social-economic surroundings and promoting the regional development - a specific vocation of Polytechnic Institutes in Portugal" [1], an important task due to its regional characteristics since it is about $40 \mathrm{~km}$ from Oporto city center, in the region across the counties of Póvoa de Varzim and Vila do Conde. With a training offer of eight Bachelor degrees, seven Post-graduate programs, seven Master's degrees, and two Post-secondary Specialization Programs, in areas that went from Accounting and Management, to Design, Hotel Management, Human Resources, Engineering, among others, ESEIG had about 1500 students and more than 100 lecturers and was one of the seven Organic Units (OU) from the Polytechnic of Porto (P.PORTO) until 2016.

Focusing in the Accounting and Management Degree, the "oldest" degree in ESEIG, it experienced several changes to its general curriculum, with the most notable being when the adaptation to the Bologna Process, in 2006. In these modifications, non-nuclear areas were the most "punished", essentially when it comes to the number of contact hours (lectures), with a reduction from 6 to 3 weekly hours in Mathematics from 2001 until now, but this adjustment was not directly followed by a reduction in the syllabus content.

In the academic year of 2005/2006 another problem arose when the minimum grade for the entry test (Specific Exam) was established at 9,5 in a 0 to 20 scale, ([2], [3]). This decision carried out a huge drop in the number of students that entered into courses witch the Specific Exam required was Mathematics A (National Exam). In that sense, many institutions made remarkable changes to the 
Specific Exam required to enter in their degrees, and in ESEIG the Accounting and Management Degree was one of these. In particular, until 2006, in the Accounting and Management Degree students had to take one of the following entry exams: Economy; Geography and Mathematics A [4]. Since 2007 the Specific Exams accepted were: Economy, Portuguese and Mathematics Applied to Social Sciences (Matemática Aplicada às Ciências Sociais - MACS) [4]. One must notice that, this last exam admits its grade to be exchanged by the grade obtained in Mathematics A or Mathematics $B$ Exam, fact that did not happen when the Math Exam accepted for entry in ESEIG was Math A (in this case only the grade obtained in that specific exam was admitted).

In Portugal there have been some "problematic" years concerning grades in the National Specific Exams, as it can be seen in several news ([5], [6], [7]). Whenever an intensive drop in student's achievements in the Specific Exams happens, all the superior scholar system feels its reflection. For example, in 2011 the average grade in Mathematics A exam (the specific test for those who apply to engineering degrees, among others) did not exceed the eight points, the average in Mathematics $B$ was 7.4 points and in Portuguese 9.1 points. Even in a direct subject related to the degree area like Economy the grades seem to be "continuously" dropping (see [8]).

It is almost impossible to determine which of the required Exams students use for their entrance grade in Higher Education Institutions (HEI) - this grade is a pondered average of their secondary studies (three years) and the Specific Exam they choose one from a "list", that is, as already mentioned, for the bachelor degree here in stake: 04 Economy, 18 Portuguese or 17 MACS (see Table 1 - to clarify the difference between Entrance Tests with the corresponding codes and exams to be performed [9]). Notice that the Specific Exam performed is not directly related to the Secondary School Area, for example, a student may enter with Portuguese from any area of studies, in that sense the student's area of studies does not determine their Specific Exam for entering higher education.

Table 1 - Portuguese HEI access - Exams to be performed as Entrance Tests a

\begin{tabular}{|c|c|c|c|c|c|c|c|}
\hline \multicolumn{2}{|c|}{ Entrance Tests } & \multicolumn{2}{|c|}{ Exams to Perform } & \multicolumn{2}{|c|}{ Entrance Tests } & \multicolumn{2}{|c|}{ Exams to Perform } \\
\hline 01 & German & 501 & $\begin{array}{l}\text { German (initiation - } \\
\text { Biennial) }\end{array}$ & 02 & $\begin{array}{l}\text { Biology } \\
\text { Geology }\end{array}$ & 702 & $\begin{array}{l}\text { Biology } \\
\text { Geology }\end{array}$ \\
\hline 03 & Drawing & 706 & Drawing $\mathrm{A}$ & 04 & Economy & 712 & Economy A \\
\hline 05 & Spanish & 547 & $\begin{array}{l}\text { Spanish (initiation - } \\
\text { Biennial) }\end{array}$ & 06 & Philosophy & 714 & Philosophy \\
\hline 07 & Physics and Chemistry & 715 & $\begin{array}{l}\text { Physics and } \\
\text { Chemistry A }\end{array}$ & 08 & French & 517 & $\begin{array}{l}\text { French } \\
\text { (continued } \\
\text { Biennial) }\end{array}$ \\
\hline 09 & Geography & 719 & Geography A & 10 & $\begin{array}{l}\text { Descriptive } \\
\text { Geometry }\end{array}$ & 708 & $\begin{array}{l}\text { Descriptive } \\
\text { Geometry A }\end{array}$ \\
\hline \multirow{2}{*}{11} & \multirow{2}{*}{ History } & 623 & History A & \multirow{2}{*}{12} & \multirow{2}{*}{$\begin{array}{l}\text { History of Culture } \\
\text { and Arts }\end{array}$} & \multirow{2}{*}{724} & \multirow{2}{*}{$\begin{array}{l}\text { History of Culture } \\
\text { and Arts }\end{array}$} \\
\hline & & 723 & History B & & & & \\
\hline 13 & English & 550 & $\begin{array}{l}\text { English (continued - } \\
\text { Biennial) }\end{array}$ & 14 & Latin & 732 & Latin A \\
\hline \multirow[t]{2}{*}{15} & \multirow[t]{2}{*}{ Portuguese Literature } & \multirow[t]{2}{*}{734} & \multirow{2}{*}{$\begin{array}{l}\text { Portuguese } \\
\text { Literature }\end{array}$} & \multirow{2}{*}{16} & \multirow{2}{*}{ Mathematics } & 635 & Mathematics A \\
\hline & & & & & & 735 & Mathematics B \\
\hline \multirow{3}{*}{17} & \multirow{3}{*}{$\begin{array}{l}\text { Mathematics Applied } \\
\text { to Social Sciences }\end{array}$} & 635 & Mathematics A & \multirow{3}{*}{18} & \multirow{3}{*}{ Portuguese } & \multirow{3}{*}{$\begin{array}{l}639 \\
239\end{array}$} & \multirow{3}{*}{$\begin{array}{l}\text { Portuguese } \\
\text { Only for severe deaf }\end{array}$} \\
\hline & & 735 & Mathematics B & & & & \\
\hline & & 835 & MACS & & & & \\
\hline 19 & Mathematics A & 635 & Mathematics & & & & \\
\hline
\end{tabular}

\section{CONTEXTUALIZATION}

Math $B$ and MACS are biennial options $\left(10^{\text {th }}\right.$ and $\left.11^{\text {th }}\right)$ in the Scientific-Humanistic courses of Secondary School (SS) system more specifically and respectively the course of Languages and Humanities and Visual Arts. The subject of Mathematics $A$ is compulsory in the other two triennial courses - Course of Science and Technology and Socio-economic sciences. MACS and Mathematics B present a more "reduced" syllabus than Mathematics A and also a smaller workload, as developed in just two years (see [10]). The topics/issues worked on MACS are quite different from those addressed in the other two subjects (Mat A and Mat B). 
More specifically, regarding MACS, being just a two year course $\left(10^{\text {th }}\right.$ and $\left.11^{\text {th }}\right)$, its contents are, obviously, "shorter" than those of a three year one, like Math $A\left(10^{\text {th }}, 11^{\text {th }}\right.$ and $\left.12^{\text {th }}\right)$, with the aggravating circumstance of MACS having less weekly working hours. Even the specific contents are quite different, beginning in the 10th year with Decision Support Methods - Mathematical Theory of Elections, Statistics and Financial Models, addressing the 11th year, Population Models and Graphs Models, passing through Probability Models and ending with Introduction to Statistical Inference.

In what concerns the Mathematics $B$, although this is present in the three school years, the weekly schedule (3h) is almost half of Mathematics A (5h), which implies that the subjects are often covered without the necessary "deepness". The issues in question are various, starting in the $10^{\text {th }}$ grade with Geometry in the Plane and Space, Functions and Graphs - General - Polynomial Functions and Statistics, passing through Periodical Movements and Non-linear Movements, where the Rational Functions are addressed $\left(11^{\text {th }}\right)$. The subjects end addressing Probability Models, Discrete Models (sequences), Non-linear Continuous Models (exponential and logarithmic), finishing with Optimization Problems.

Regarding the Mathematics A contents, the subjects are covered in more depth and there is a greater concern for scientific rigor. Thus, in a similar minimalistic way, the program comes down to the following main points along the three years: Geometry in the Plane and in Space $\left(10^{\text {th }}\right.$ and $\left.11^{\text {th }}\right)$; Analytic Geometry; Function and Graphics: Generalities about Functions; Descriptive and Inductive Statistics; Introduction to Differential Calculus - Rational and Radical Functions, Exponential and Logarithmic Functions $\left(11^{\text {th }}\right.$ and $\left.12^{\text {th }}\right)$; Rate of change and Derivative Function $\left(11^{\text {th }}\right.$ and $\left.12^{\text {th }}\right)$; Real Sequences $\left(11^{\text {th }}\right)$; Probability and Combinatorics $\left(12^{\text {th }}\right)$; Trigonometry and Complex Numbers $\left(12^{\text {th }}\right)$.

With different skills developed in SS, these students came all "into the same bag" where the contents worked were the ones presented in the following image (Fig. 1).

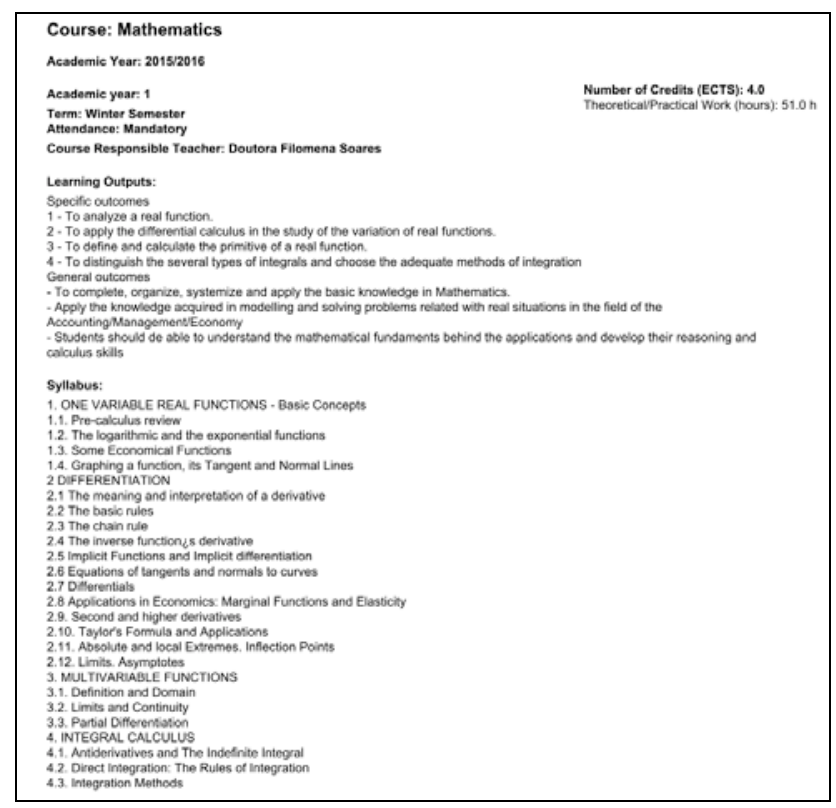

Figure 1 - Mathematics Course Syllabus (excerpt)

This was the challenge that made us try something in the first semester of the first year, where these students feel even more exacerbated the impact of entry into higher education, self-questioning is often in terms of choices really wants in terms of "capacity" for the pursuit of studies, because as professors of this UC can't wait that they have acquired skills and knowledge in topics that never have analyzed, studied or even know.

It is not an easy task to teach Mathematics to students with so different backgrounds and it is not possible to move forward without mentioning that all these "dealing problems" seem to be a common feeling among many HEI. Speaking only about the Bachelor Degree in Accounting and Management in Portugal, it is important to look "aside", that is, what is happening in "neighbor" degrees? Well, as it is accessible to anyone interested in these matters, we can look for some insights. 
Even though not having access to the real Specific Test that candidates used to enter these Degrees, the following information just distinguishes the Specific Test required to enroll these Degrees in Accounting/Administration Area. First, in Table 2, it is shown the list of available degrees (directly related to Accounting) offered by Portuguese Public Education sector and its regional distribution can be seen in Fig 2. Notice that there are several degrees in Accounting that registered less than twelve students in the $1^{\text {st }}$ stage of the National application process, for example, in 2013 the Polytechnics of Guarda and Viseu, registered just one candidate entering this Degree in this first stage of the selection process.

Table 2 - Bachelor Degrees in Accounting Area - Portugal 2015

\begin{tabular}{l|l}
\hline Degree Designation & Institution \\
\hline Finance and Accounting & ISCTE - Lisbon University Institute \\
\hline Accounting & School of Accounting and Administration of Aveiro \\
\hline Accounting & Polytechnic of Cávado and Ave - School of Management \\
\hline Accounting & School of Technology and Management of Bragança \\
\hline Accounting & Polytechnic Institute of Guarda - School of Technology and Management \\
\hline Accounting and Management & School of Accounting and Administration of Lisbon \\
\hline Accounting and Management & School of Accounting and Administration of Porto \\
\hline Accounting and Management & Polytechnic Institute of Porto - School of Industrial Studies and Management \\
\hline Accounting and Management & School of Accounting and Administration of Coimbra \\
\hline Accounting and Management & School of Technology and Management of Lamego \\
\hline Accounting and Finance & Leiria Polytechnic Institute - School of Technology and Management \\
\hline Accounting and Finance & Setúbal Polytechnic Institute - School of Business Administration \\
\hline Accounting and Taxation & School of Technology and Management of Santarém \\
\hline Accounting and Financial Management & School of Management of Idanha-a-Nova \\
\hline Accounting and Public Management & School of Accounting and Administration of Coimbra \\
\hline
\end{tabular}

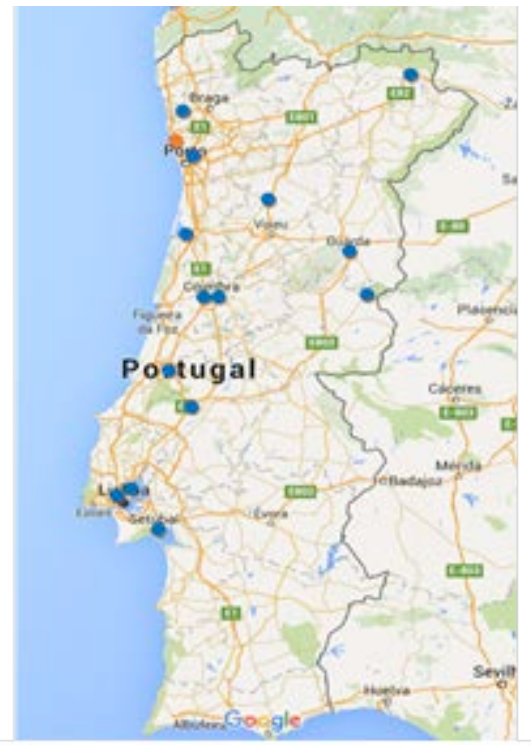

Figure 2 - Regional Distribution of Accounting Area Bachelor Degrees

One must note that only one (from ISCTE), among these fifteen degrees, requires Math A ("19 Math" National Exam) in order to enter this course. The other fourteen degrees open their doors to almost every area in Portuguese secondary education, since the specific exams required are mainly the same as in our case (see Fig. 3). Notice also that "16 Math" exam accepts grades from Math A and Math B exams, while "17 MACS" accepts grades from all Math exams (A, B and MACS) and exams like "18 Portuguese" and "09 Geography" has a wide range of secondary areas attained. 


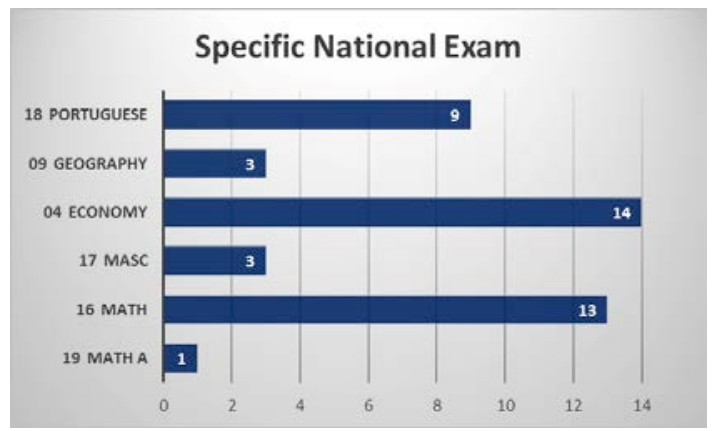

Figure 3 - Accounting Area Bachelor Degree - Specific Exams

Apparently it is licit to think that the problems we have been experiencing, with the substantial differences in Math background competences of our students, for the past few years are, at least, a national one and, unfortunately, we don't hear much "comments" over that issues.

Facing an audience with the constant feeling that for half of them we speak "Chinese", and for the other half, it seems that we are talking with five years of delay (a kind of "ABC" to someone who reads fluently) and confronted with some unsuccessful assessment rates, being "teaching lovers" we felt it was important to try to revert something in this global process.

\section{PEDAGOGICAL PRACTICE DESCRIPTION}

This proposal was yearly presented at the Department of Mathematics of ESEIG and submitted after to the Technologic-Scientific Council, in order to be approved, since 2012. Since that year, it was functioning, despite all the financial constraints that we have been through. The responsible for the Mathematics Curricular Units in this Degree $\left(1^{\text {st }}\right.$ and $2^{\text {nd }}$ academic years), came to propose the maintenance this measure, which we will briefly describe in this section, reducing one class in the first semester of second year of this degree, in the course of Probabilistic Methods (working with more than 70 students), allowing to annually perform this workload duplication without increasing the number of needed teachers for courses affected the department.

\subsection{Objectives and target audience}

We can state that the primary objective of this measure goes beyond the increase in the "success" rates at curricular unit (CU) of Math in the 1st semester of the 1st year of the Accounting and Management Degree, as much as this is almost the only objectively "measurable". The goal was, in reality, a "leveling up" of knowledge and skills of these students in the area of mathematics, promoting its connection, where and when possible, with the nuclear areas of the degree course, trying to increase the level of satisfaction with the chosen degree.

Generally, the "target audience" of the action that we describe here were all students enrolled at Math $\mathrm{CU}$ of Accounting and Management Degree, however this "target audience" should be properly analysed in order to understand clearly the issue in question, with regard to courses attended in the SS (see Fig. 4 and 5). Globally speaking, as Fig. 4. and Fig. 5 show, there are not almost any differences between the overall candidates' area and the area of those who manage to enrolled this Degree. But the challenge to be faced, despite being related to the field of study, just to go a little beyond this issue, since the Specific Test used for entering this Degree was not, frequently, the Mathematics A exam. Almost all the data presented in this section are on public domain [11]. 


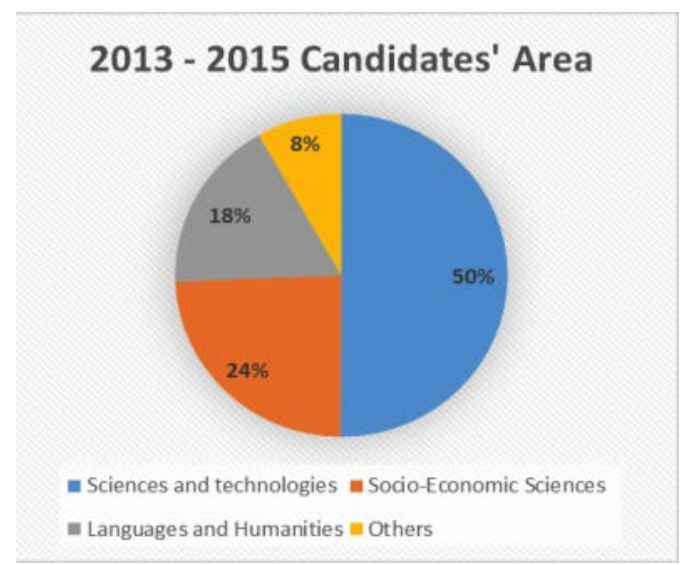

Figure 4 Candidates to Accounting and Management degree in ESEIG - Study area

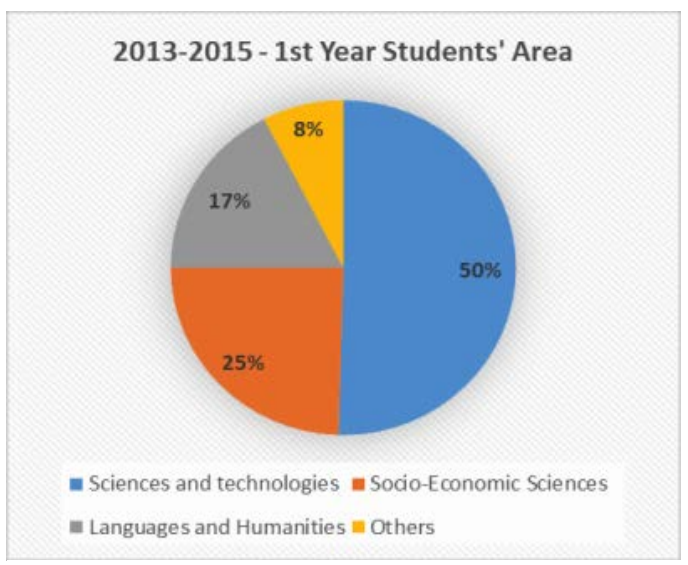

Figure 5 - Students enrolled in Accounting and Management in ESEIG - Study area

In Fig. 5, we can see that $75 \%$ of students attended the areas of Science and Technology and Socioeconomic Sciences, however, as you can see in Fig. 6 only $26 \%$ used Mathematics A National Exam as Entrance Examination. This information was retrieved from the data obtained in an annual enquiry that all students entering Accounting and Management Degree at ESEIG have been answering, in the school Moodlle platform since 2013, developed by their Math teachers. It seems to be the only way to access this type of information, not available in any public data base that we know of.

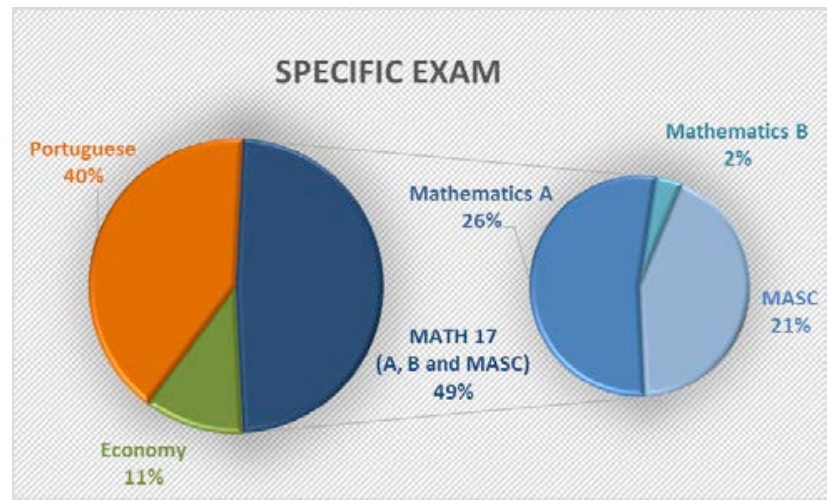

Figure 6 - Accounting and Management ESEIG - National Exam performed - 2013 to 2015

So, more than $1 / 3$ of students registered in the first year course of Mathematics of the Accounting and Management Degree and the vast majority of repeating students joined this Bachelor Degree without attending Mathematics (A or B) in secondary education. This is in addition to the 9th grade, these students only have, on its academic curriculum eventually the Curricular Units (CU) Quantitative Methods or Mathematics Applied to Social Sciences (MACS), existing in the 10th year. Note also that this $9^{\text {th }}$ grade was, at least, completed three years before entering to our school (and "fled Mathematics" in secondary education, there will certainly be an underlying obvious reason - struggling with difficulties in this subject).

The general lack of motivation in these students, in a CU where the use of basic concepts is constant, was fundamentally due to the fact that they could not keep up with all the new or even "revision" themes, feeling unable to work these concepts in an autonomous way. So, in a sense, the proposed measures were attempting to provide a type of "more targeted education" to the general and specific gaps of those students who enter without having seen (or succeeded) Mathematics in secondary education. 


\subsection{Methodology}

At the registration moment, the academic services of the ESEIG informed students of the date and time they would have to take a Diagnostic Assessment Test (DAT), giving students a brief description of the purpose of that test and noting (by signing each student) which students who have been warned. The date of the completion of this test has been in the last three years, the first morning time of the first day of school, prior to the schedule choice.

According to the results obtained in this test (visible for students when they finish, as part of the feedback submitted) students are advised to choose math classes with different number of weekly contact hours, however, these options are just mere "advice" and no student was ever forced or compelled to enrol in any class against their will.

When school activities begin, all students who have opted for a class load of 6 contact hours assume, before teachers, a compromise from September to January in terms of class frequency, since it is not "recommendable" to exchange class, at least until the first assessment moment, due to the notorious differences in schedules of different classes. There is a concern on the part of the professors of this $\mathrm{CU}$, in the development of differentiated pedagogical practices, offering students a wide range of materials in digital format, accessible online, promoting their sequential utilization according to the needs of each group/class.

In this $\mathrm{CU}$ the continuous assessment is performed through two moments of classroom assessment (two tests) with different weights $(70 \% \mathrm{~T} 1+30 \% \mathrm{~T} 2)$ and several small tests online (implemented in ESEIG Moodle Platform), distributed throughout the semester in order to promote a "true" continuous evaluation and monitoring continuous learning results. It must be mentioned that the first moment of classroom assessment was performed when have passed about $2 / 3$ of the Term weeks (not the middle of the semester) to enable the realization of the same test for all students enrolled at $\mathrm{CU}$ regardless of number of class contact hours that they attend. The learning objectives for the first test were items 1 to 3 (see Fig.1), leaving for the second only item $4-$ Integration. As the degree central areas are Accounting, Management and Economy, we tried to focus all the problems in applications to these ones, whenever possible, and when reviewing secondary school subjects, we practically "pass over" Trigonometry, Trigonometrical Functions and Complex Numbers, in order to accomplish in two months "leveling up schedule".

\subsection{Evaluation}

Although the test results are "mute", in the sense that the diagnostic test detailed analysis goes beyond the scope of this article, we present in Fig. 7, the percentage results in the three years in analysis -2013 to 2015 . Since it has been composed of the same questions and feedback in the years here presented we must notice a dropping tendency in these global results - an average of $60.5 \%$ in 2013 (standard deviation (SD) of 20.5), 50.2\% in 2104 (SD = 23.2) and $52.7 \%$ in 2015 (SD = 19.7). Though we have the results from a Diagnostic Test in 2012 (done and corrected in paper) we do not present them since the questions in stake were not the same and, as so, the corresponding results fail to be compared.
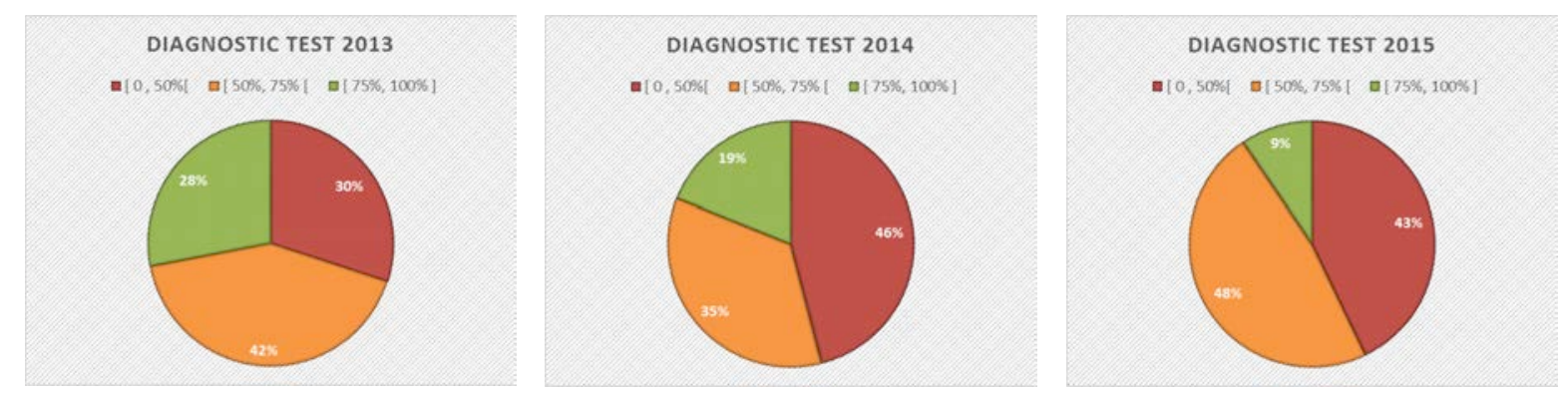

Figure 7 - Results of the Diagnostic per year (2013-2015)

The correspondent automatic feedback, as already mentioned, was:

Advised to attend class with 6 weekly contact hours;

Advised to attend class with 3 weekly contact hours;

At the student criteria. 
In the next images (Fig. 8 and 9) we can see students' schedule choice, from the three classes available in the beginning of the semester (two with 6 weekly contact hours and one with 3), for the three years in analysis - note that, for Fig. 8, we withdraw from the total of registered students the "repeating" students, but in Fig. 9, we show the non-freshmen inscriptions in these different classes, in order to distinguish reactions to Diagnostic test and students' future perceptions.
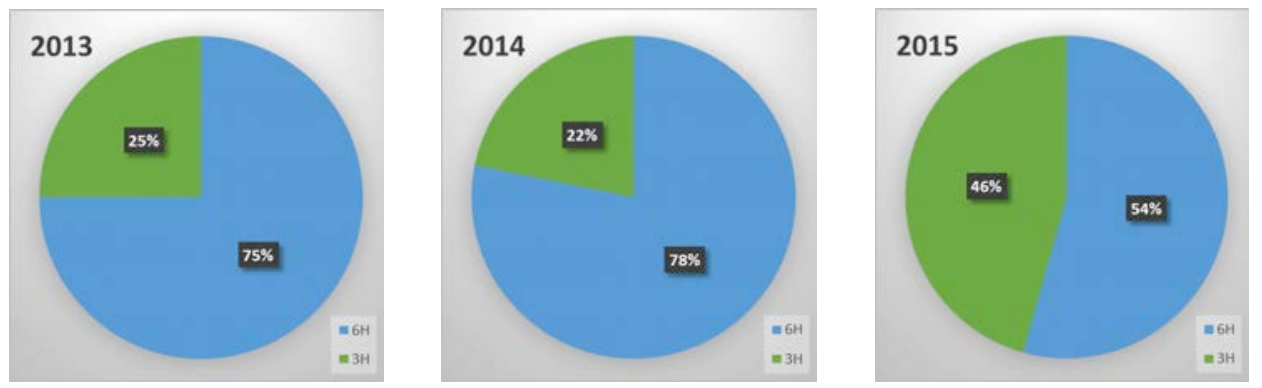

Figure 8 - Freshmen's options - weekly contact hours
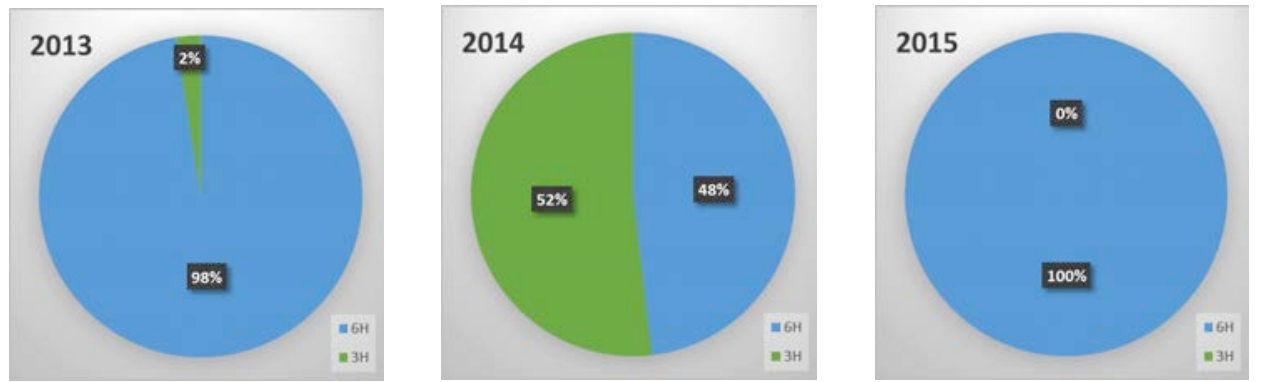

Figure 9 - Non-Freshmen's options - weekly contact hours

Notice that non-freshmen students are, mostly speaking, very conscious of their competences and seek to overcome their difficulties, principally if they feel someone cares. As we can see, the options are quite different, but there are several factors to take notice of - usually even when registered in a 3hour contact class, if they can they assist to 6 hours. On the other hand, sometimes schedules are not completely compatible with other years' courses and they don't get to assist as often as they should.

Since "a picture it's worth a thousand words", we will present some of the results obtained in Mathematics CU, by Accounting and Management Degree in ESEIG. We will try to analyze their evolution over the past few years, relating these, when possible, with the measures implemented to combat failure. In Fig. 10 we can visualize the evolution of three indicators, globally speaking: Relation between Enrolled students (I) and Assessed ones (A), in the percentage A/E; Relation between Successful students (S) and Assessed ones (A), in the percentage S/A and Global relation between Successful students (S) and Enrolled ones (E), in the percentage S/E. 


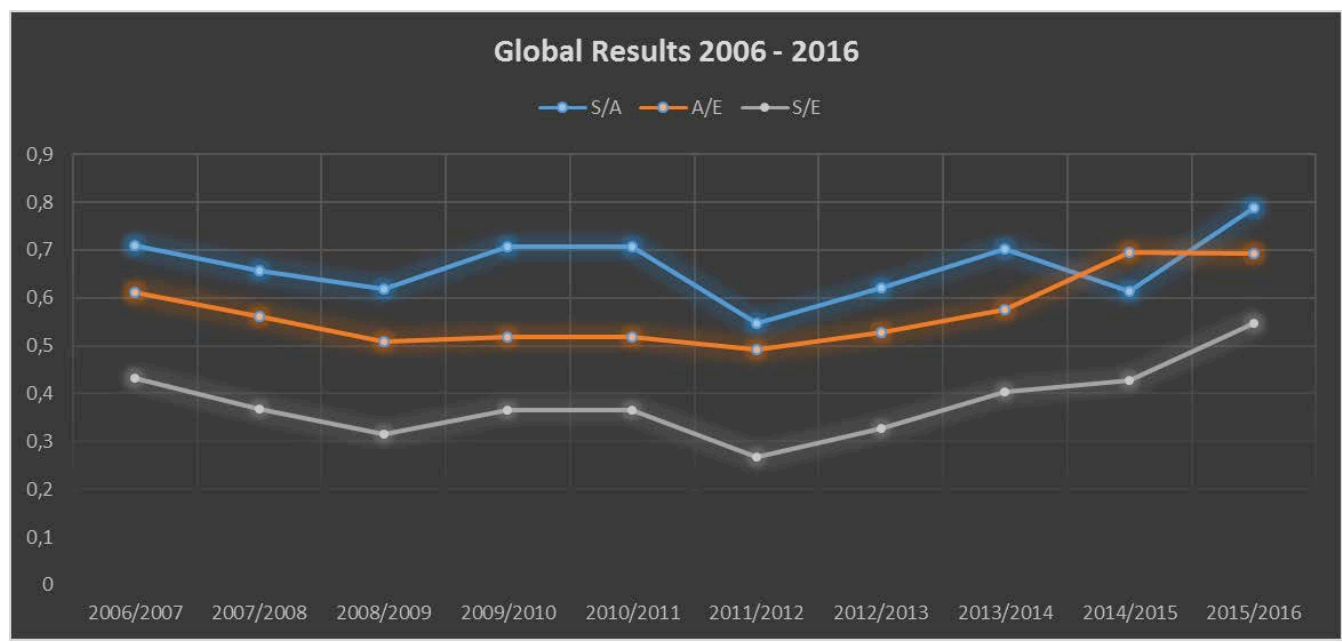

Figure 10 - Mathematics - Assessment indicators

Even though there are many issues that imply these results, some of these external, we noticed among others: with the changes made in the criteria to enter this high school program in $2005 / 2006$, its impact is shown in a visual and continuous drop of all indicators (2006-2009). The small raising movement in the two following years is closely connected to the fact that many students were finishing this program after the Bologna adaptation process, struggling to get their degrees. Note that, since many courses have changed from academic year and new different courses appeared, the transition process has impact over the number of years that students took to complete their course. These often fail to end the courses of mathematics, trying to carry them out only when they have to finish their Degree.

Detaching, for the last three years, our analysis in terms of number of hours of each class, we can see the results transmitted through Fig. 11. From a different point of view, this question also justifies, at least part of, the difference between the rates of Successful / Enrolled and Successful / Assessed, which is also one of our concerns.
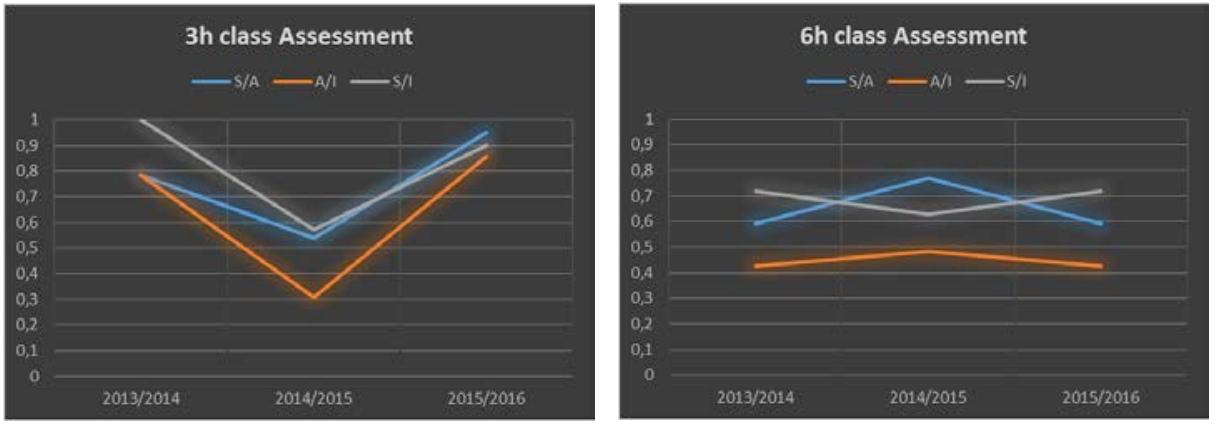

Figure 11 - Assessment rates per number of class contact hours

It is interesting to compare the results shown in this last set of images with the ones on Fig. 7 and 8 . When the number of repeating students in a 3-hour class is high this is directly reflected in the rate drop.

Although we have made an annual survey of opinion, anonymous (filled in on paper in the last class of the semester by students of every class), that has been a support tool in the justification for the maintenance of this measure, we decided, in May 2016, to draw up a survey of opinion/global assessment, to which answered 130 students of various years of the LCA, since this was the last year of the program. In the next "flow chart" (Fig. 12) all the direct answers given by students can be seen, since no one better than their own will be able to "say his righteousness". This survey was anonymous and answered electronically. 


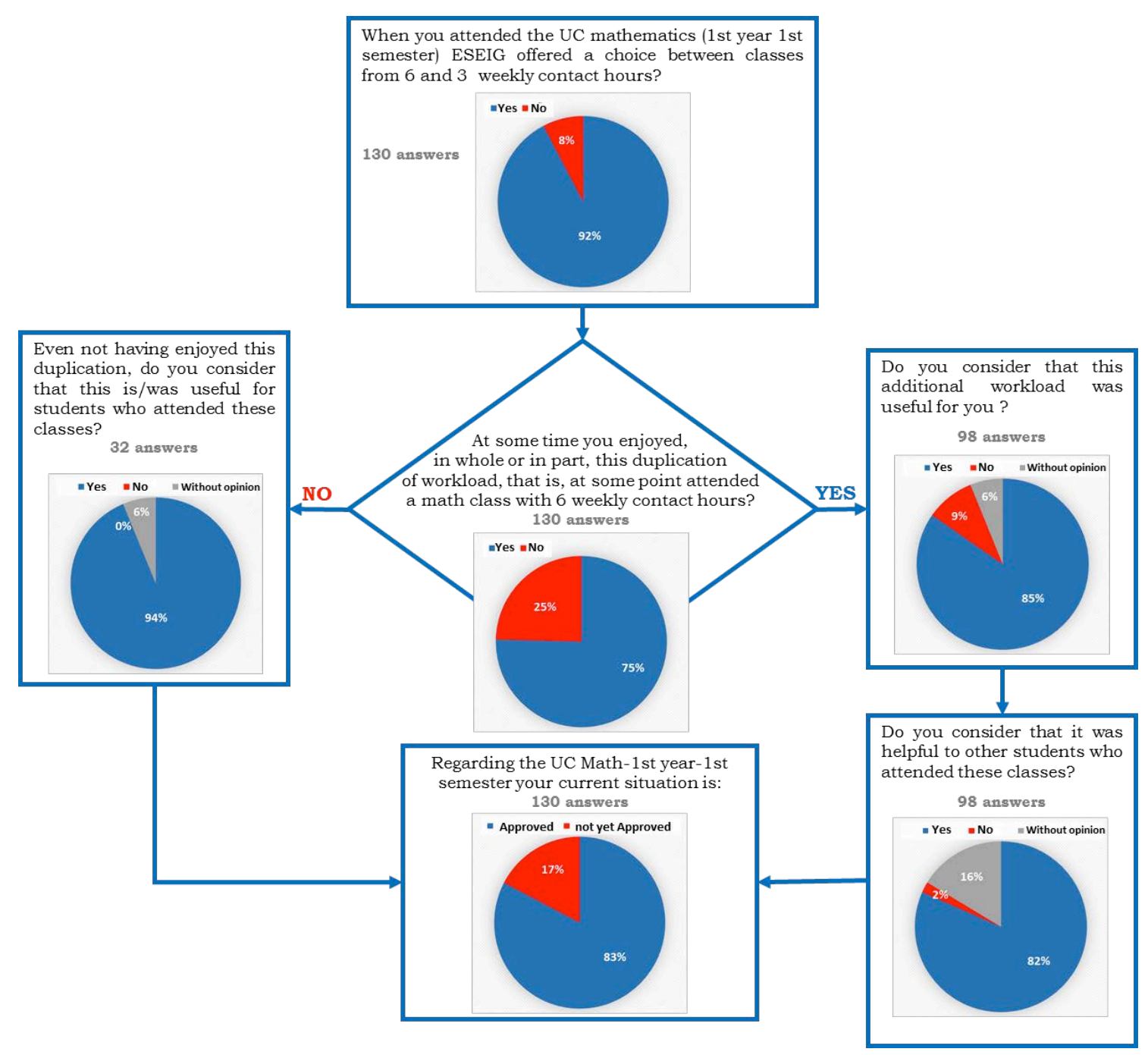

Figure 12 - Inquiry - Accounting and Management students - May 2016

It seems to us, once again, that images speak for themselves, this feedback is truly encouraging and rewarding for teachers who gave themselves to this little project.

\section{CONCLUSION}

The transferability of this small project is undoubtedly a very important issue, even in internal terms given the change that occurred in ESEIG with its transformation in the School of Hospitality and Tourism and the relocation of much of its formative offer and the extinction of its Accounting and Management degree. Thus, this project, as until now existed, ends here, because as of the next school year, 2016/17, the first year of this degree will not operate. It does not seem difficult to implement in other undergraduate and/or other institutions, with the same problem in the admission of students with different "mathematic history". In this sense, we leave here some of the important points that should be taken into consideration while embracing a similar methodology:

1 Identify previous skills and knowledge that supposedly predate the $\mathrm{CU}$ program in which the measure will be applied;

2 Develop a well-designed ADT, preferably with automatic correction, and carry it out before the real start of school activities;

3 Ask for the collaboration of academic services in order to ensure that all students enrolled in the first year/first time are informed of its implementation and its objective;

4 Ensure that the classes with more contact hours present schedules as "nice" as the other; 
5 Ensure that all students are evaluated the same way, performing the same tasks and the same evaluation moments (as mentioned);

6 Certify that the students in the usual classes are not penalized by the existence of "special" classes fulfilling the $\mathrm{CU}$ program.

Despite being labor-intensive and requiring a very strict daily scheduling, it seems to us that the overall results were positive and worth the effort. We would like to have presented a detailed diagnostic assessment tests as well as having promoted the realization of the same at the end of this process (semester), however we feel in a very real and concrete way, that the objectives settled in the implementation of this measure were and have been fulfilled. There are, obviously, several difficulties to keep in mind as, for example, financial restrictions; frequent high absenteeism rates; low motivation to learn, among others. As any other plan this has its fails, not exempt of objections and obstacles either in its implementation or in its pursuit, however, the development of a conscientious work is not possible when we notice students' difficulties without, at least, trying to do something

\section{REFERENCES}

[1] School of Management and Industrial Studies (ESEIG), https://www.eseig.ipp.pt/en/

[2] DGES - Legislação. (n.d.). Retrieved April 15, 2016, from http://www.dges.mctes.pt/DGES/pt/Estudantes/Acesso/ConcursoNacionalPublico/Legislacao/ see "Decreto-Lei n. ${ }^{\circ}$ 26/2003, de 7 de fevereiro"

[3] Governo mantém 9,5 como nota mínima de acesso ao ensino superior. (2005, April 22). Retrieved May 01, 2016, from https://www.publico.pt/educacao/noticia/governo-mantem-95como-nota-minima-de-acesso-ao-ensino-superior-1221405

[4] DGES - Aquiver. (n.d.). Retrieved May 1, 2016, from http://www.dges.mctes.pt/DGES/pt/Estudantes/Acesso/ConcursoNacionalPublico/Guias/Arquiv o/

[5] Candidaturas - Médias para o ensino superior podem descer este ano. (2011, August 10). Retrieved April 25, 2016, from http://www.dn.pt/dossiers/tv-e-media/revistas-deimprensa/noticias/interior/medias-para-o-ensino-superior-podem-descer-este-ano-1949517.html

[6] Número de colocados na primeira fase do ensino superior volta a descer. (2012, September 09). Retrieved May 1, 2016, from http://www.rtp.pt/noticias/educacao/numero-de-colocados-naprimeira-fase-do-ensino-superior-volta-a-descer_n585517

[7] Exames do Secundário: Média sobe a Português e desce a Matemática. (2014, July 14). Retrieved April 21, 2016, from http://www.educare.pt/noticias/noticia/ver/?id=28062

[8] Economia: Sempre a descer. (2014, November 13). Retrieved May 1, 2016, from http://visao.sapo.pt/actualidade/sociedade/economia-sempre-a-descer=f802011

[9] DGES - Provas de Ingresso. (n.d.). Retrieved May 01, 2016, from http://www.dges.mctes.pt/DGES/pt/Estudantes/Acesso/ConcursoNacionalPublico/Provasdelngr esso/provasingressoexames.htm

[10] Decreto-Lei n. ${ }^{\circ}$ 139/2012, de 5 de julho. Diário da República n¹29/2012 - I Série. Ministério da Educação e Ciência. Lisboa.

[11] DGES - Estudos e Estatísticas. (n.d.). Retrieved April 15, 2016, from

http://www.dges.mctes.pt/DGES/pt/Estudantes/Acesso/Estatisticas/EstudosEstatisticas/ 